\title{
A COMPARATIVE ANALYSIS OF THE SENTENCE PLACEMENT OF ADJECTIVES FROM THE ALBANIAN TO THE ENGLISH LANGUAGE
}

\author{
Majlinda Nuhiu ${ }^{1}$
}

Abstract: Our main aim in this research paper is to analyze the place of adjectives in translated paradigms from the Albanian to the English language. The corpus is taken from translated books of the well known Albanian writer, Ismail Kadare, translated into the English language, exclusively by native English translators. Firstly, we'll try to present the general place of adjectives in each language separately. Secondly, by comparing and contrasting the corpus of the both languages we will try to find out numerous and diverse similarities and differences in both of the languages, and with the help of the corpus we will check the results. With the help of Levenstone's (1965) translational' paradigms we'll try to find out if adjectives in the Albanian language change their sentence position after they are translated into English. The technique being used is an objective technique, working with the corpus, one-way translation and a group test of Gjorgevic (1982).

UDC Classification: 81; DOI: http://dx.doi.org/10.12955/cbup.v6.1233

Keywords: adjectives; position; translation paradigms;similarity;difference.

\section{Methodology}

The methods used during this scientific research study are descriptive, comparative and synchronic. With the help of a descriptive method we'll try to notify and describe the place of adjectives in the sentence in both of the languages separately. While, with the help of comparative method we'll try to compare and contrast the two languages concerning the sentential place of adjectives in the translated paradigms taken from three of Ismail Kadare's books: Broken April, The General of the Dead Army and The Three Arched Bridge. The synchronic method will help us see and classify the actual flow of these processes in both languages, Albanian and English.

\section{The general sentence place of adjectives in the English language}

Adjectives are words that modify nouns and pronouns. In the English language they always appear immediately before the nouns or the noun phrase that they modify, and when indefinite pronouns are modified by an adjective, they come after the pronoun. Generally, according to Bauer (2004) adjectives could be seen in two main positions: attributive and predicative. Attributive adjectives appear as noun modifiers while predicative adjectives are those that are likely to occur in the copular construction. It has also been pointed out that most attributive adjectives have predicative uses. Here is an example: a happy person vs. They are happy. According to Quirk and Greenbaum (1991) adjectives can be syntactically sub classified into: attributive only, predicative only, intensifying adjectives, restrictive adjectives, adjectives related to adverbs and adjectives related to nouns.

\section{II.1.1. Attributive adjectives}

Bauer (2004) names attributive adjectives as postmodifiers since they come after the head in a noun phrase, they are comprised of prepositional phrases and clauses. They give extra or specific information about the noun. Here are some examples given by him: Ex: A tall man with grey hair. Ex: That antique table she bought last year. Since there are different types of adjectives Baskerville \& Sewell (1986) suggested that adjectives that denote attributes should be in a specific order before the noun, and that order of adjectives in English language is: determiners, observations, size, shape, age, color, origin, material and qualifiers. Ex: A lovely big round, white table. Ex: He bought an interesting, small, rectangular, red car. Ex: My friend lives in a beautiful, gigantic, new marble house. According to Bolinger (1967) adjectives are attributive when they premodify the head of a noun phrase as in the following examples: a small garden, a popular ballad. Generally seen adjectives can be attributive, which means that they occur before the nouns and after the determiners or they can be a part of the predicate of the sentence as in the examples below: Ex: Your pretty daughter is here. Ex: That man is a fool. According to Alexander (1988) adjectives which restrict the reference of the noun, are always attributive; as in the following examples: 'certain' (a woman of a certain age), 'chief' (my chief complaint), 'main' (my main concern),'only' (the only explanation), 'principle' (the principle reason), 'sold' (my sold interest). These adjectives are only used attributively, expect for 'certain' and 'particular' which can change in meaning. Noted by Quirk and Greenbaum (1991) a few adjectives with emotive value are restricted to attributive position though the scope of the adjective extends to

\footnotetext{
${ }^{1}$ State University of Tetovo, Ilindenska nn, 1200, Tetovo, Republic of Macedonia, majlindanuhiu@gmail.com
} 
the person referred to by the noun. Here are some examples: you poor man, my dear lady, that wretched woman.

\section{II.1.2. Predicative adjectives}

Adjectives are predicative when they function as the subject complement or object complement as in the examples: Ex: He seems careless - Cs; Ex: I find him careless - Co. Generally seen, adjective are subject complement not only to noun phrases but also to finite clauses and nonfinite clauses, as in the following examples: Ex: That you need a car is obvious. Ex: Whether she will resign is uncertain. An adjective could also be an object complement when there is co-reference between direct object and object complement which is stated by Alexander (1988): Ex: The situation made Mr. Hardy was courageous and even a bit daring. Adjectives according to Quirk and Greenbaum (1991) which are restricted or virtually restricted to predicative position are the most like verbs and adverbs. They tend to refer to a condition rather than to a characteristic. The most common are those referring to the health of an animate being: Ex: He felt ill/ poorly < both esp BrE> / well/faint/unwell. An enormous group of adjectives that are restricted to a predicative position, can include adjectives which can take complementation, here are some examples: able (to + infinitive), fond (of), afraid (that, of, about), glad (that, to), conscious (that, of), tantamount (to) etc.

\section{II.1.3. Postpositive adjectives}

There are also certain adjectives that in combination with certain words are always postpositive, follow the noun or the pronoun that they modify.

a) Postposition is obligatory for proper nouns in the meaning as in the following examples: Ex7: the City of London proper.

b) Adjective can be postpositive in several institutionalized expressions, like the following ones: the president's elect, heir apparent, attorney general, notary public, body politic, and proof positive.

c) Adjectives can be postpositive ending in -able and -ible, when they are modified by another adjective in superlative degree, here are some examples given by Quirk and Greenbaum (1991). Ex: the best use possible/ Ex: the greatest insult imaginable. Another issue about postposition adjectives is that postposition is usual for absent, present, concerned, and involved, as in the example: Ex: The soldiers present were his supporters.

\section{II.1.4. Intensifying adjectives}

There are some adjectives that have heightening effect on the noun they modify, according to Quirk \& Greenbaum (1991) there are three semantic sub-classification of intensifying adjectives: a) emphasizers; b) amplifiers and c) downtoners

Emphasizers have a heightening effect and are generally attributive only, eg: A true scholar, plain nonsense. Amplifiers are central adjectives if they are inherent and denote a high or extreme degree: a complete victory- The victory was complete; great destruction- The destruction was great. On the other hand, when they are noninherent amplifiers are attributive only: A complete fool- The fool is complete; A firm friend - The friend is firm. Here are some examples where adjectives as amplifiers are attributive only: a great supporter, a perfect stranger, total irresponsibility. Downtowners have a lowering effect, scaling downwards from an assumed norm. They are relatively few: slight in a slight effort, feeble in feeble joke. They can also be ignored because they are generally central adjectives.

\section{II.1.5. Restrictive adjectives}

Restrictive adjectives restrict the reference of the noun exclusively, particularly or chiefly and they are used attributively. Here are some examples with noun phrases include: A certain person; his chief excuse.

II.1.6. Adjectives related to adverbs

Some of noninherent adjectives that are only attributive can be related to adverbs; even they are not intensifying or restrictive, ex: My former friend, [formerly my friend]; an old friend, [a friend of old].

\section{II.1.7. Adjectives related to nouns}

Denominal adjectives tend to be restricted to the attributive position: An atomic scientist [a scientist specializing in ten theory of atoms]; a criminal court [a court dealing with crime]. 


\section{The general sentence place of adjectives in the Albanian language}

The word order of adjectives in the Albanian language is noun+adjective. Adjectives follow the noun that they modify (Beci, 2004) as in the following examples: Baba i dashur, Lule e bukur, Zana bleu një fustan të bukur. But they can also precede the head, adjective+noun in this case the order is ligature+adjective+noun. In the Albanian language, predicative adjectives also keep the ligature as in the following examle: I ziu baba u kthye nga kurbeti pas shumë vitesh. Citaku (2009) classifies adjectives in the Albanian language into frontal and non-frontal. Frontal adjectives are those that have a bivalent role in the sentence, the role of the subject, noun, and the role of the adjective at the same time and they stand at the front of the sentence meaning at the beginning of the sentence as in the following examples: I riu erdhi nga dritarja. I keqi i mirë nuk behet. In this classification are also included adjectives with foreign derivation that within the Albanian language haven't been decoded in their component parts, as in the following examples: absolut, dekadent, elegant etc. Frontal adjectives are less used in comparison to non frontal adjectives. When it comes to non frontal adjectives which are formulated with derivation - with prefixes, most productive suffixes are: $p a$ - and jo- forming adjectives with negative meaning: i pabotuar, i padukshem, jozyrtar, jonormal etc. A less productive prefix it is the prefix mos- : mospërfilles, mosmiërnjohës.

Generally seen, in the Albanian language the place of adjectives in the sentences is either attributive, they precede the noun that they modify or predicative, they follow the noun. But, when used in the attributive position they should be adjusted in number and gender with the noun that is connected. There are cases when they follow the noun that they modify and are remarkable in requiring a particle preceding them that agrees with the noun, eg: djalë $i$ ri (masculine), vajzë $e$ re (feminine). The adjectives which function as predicative adjectives show the quality or characteristic of the subject. Unlike the predicative determinant that is expressed with noun, the predicative determinant expressed with adjective cannot refer to a direct object, but when predicative determinant refers to the subject, we can find it next to the transitive verb: Ex: Ajo e kuptoi që unë $e$ vërrejta $i$ mahnitur dhe u bë flakë në

Ex: Gjika kafshonte buzët $i$ shqetësuar.

fytyrë.

When it comes to the adjective phrase, formulated with the formula adjective+noun with the prefix $n g a$, and the adjective in the affirmative degree, they express relations between a quality and a thing, it limits the scope of the quality as in: Ex:I lodhur nga rruga Ex: I habitur nga bukuria. The adjective phrases (adj+ adv) are used the most, usually adjectives express quality, and the adverb usually goes after the adjective. Most of these adverbs are adverbs of quantity like the following ones: pak, mjaft, shumë, tepër etj. Ex: Mjaft i mirë. Pak i mirë. The adjective phrase (inf +adj) are very limited in number: here are some infinitive adjectives given as examples by Akademia e Shkencave e Shqiperise (2002): i aftë, i paaftë, i pafuqishëm etj. Their use it's very rare, because they compete with adjectives+word direct object with the predicative in subjunctive. We also have some examples for these adjectives given by Akademia e Shkencave e Shqiperise (2002) Ex: I paaftë për të drejtuar. Ex: Të gatshëm që të ndihmonin. When it comes to another formulation of the adjective phrase we should mention (pron+adj) which are less used. Ex: Kish dicka të vecant në veshtrimin e tij. Ex: C'te re kemi sot? Sot s'kemi asgëj të re.

\section{Comparing the sentence place of adjectives when they are translated from the Albanian to the English language}

We have tried to compare the position of adjectives in sentences after they are translated from Albanian to English with the help of translational paradigms which are exclusively done by native English translators taken from the books of the famous Albanian writer, Ismail Kadare. Firstly, we wrote down all the adjectives and their place in the sentence in the Albanian language together with their translated counterparts in the English language. Then we grouped them according to the most frequently used positions of adjectives and adjective phrases and finally we classified them into the most frequent major groups.

During the process of noting down, we saw that the writer himself had the habit of using simple adjectives composed of the formula (noun+adjective), used for description and modification. This was the most frequent case noticed in Ismail Kadare's books where adjectives in the Albanian language where used after the word that they modify while in the English translated paradigms the place of the 
adjectives was before the word that they modified. In translation from Albanian to English, the adjectives switched their position in the sentence from predicative to attributive. We named this correlation as different correlation since the position of the adjectives in both sentences was completely in a different place while the construction was the same. Both of the constructions in both of the languages were an adjective that modifies a noun. Here are some corpus examples in order to illustrate the case:

\begin{tabular}{|c|c|}
\hline Albanian language & English language \\
\hline $\begin{array}{l}\text { Ex1: Nëqoftëse konti do të pranonte, të } \\
\text { gjitha këto do të shkruheshin në një } \\
\text { marrëveshje } \\
\text { të hollësishme një për një dhe pikë për pikë } \\
\text { Kadare } \frac{(1980)}{}\end{array}$ & $\begin{array}{l}\text { Ex1: If the count agreed, this would all be laid } \\
\text { down in a detailed agreement (item by item } \\
\text { and point by point). Hodgson (1997) }\end{array}$ \\
\hline Albanian language & English language \\
\hline $\begin{array}{l}\text { Ex2: Tani është thellësia maksimale, tha prifti. } \\
\text { Kadare (1980) }\end{array}$ & $\begin{array}{l}\text { Ex2: They have reached the maximum depth the } \\
\text { priest said. Colman }(2000)\end{array}$ \\
\hline Albanian language & English language \\
\hline $\begin{array}{l}\text { Ex3: Si një shpend krenar e i vetmuar. } \\
\text { Kadare (1980) }\end{array}$ & $\begin{array}{l}\text { Ex3: Like a proud and solitary bird. } \\
\text { Colman (2000) }\end{array}$ \\
\hline
\end{tabular}

Within the case of different correlation, we noticed two sub cases, where the elements constructing the adjective phrases in English and Albanian language don't have the same except not having the same position also the construction of the adjective phrases was not formulated by the same number of elements inside them. There were two frequent sub cases that we named as extensive and intensive correlation. Intensive correlation was the case when there is a complex adjective phrase in the Albanian language used predicatively after the noun it modified but, in the translated paradigm in the English language there is a simple adjective phrase to express the overall idea and it is in the attributive position. To illustrate this case there are the examples below:

\begin{tabular}{|l|l|}
\hline Albanian language & English language \\
\hline $\begin{array}{l}\text { Ex4: Konti, me sytë } \text { e lodhur, të skuqur anëve, } \\
\text { vështronte herë peshkopin, herë sekretarin e vet. } \\
\text { Kadare (1980) }\end{array}$ & $\begin{array}{l}\text { Ex4: The count with weary bloodshot, looked } \\
\text { first at the bishop and then at his own secretary. } \\
\text { Hodgson (1997) }\end{array}$ \\
\hline Albanian language & English language \\
\hline $\begin{array}{l}\text { Ex5: Vazhdonte koha e keqe me llohë. } \\
\text { Kadare (1980) }\end{array}$ & $\begin{array}{l}\text { Ex5: The month of St Ndreu began and ended } \underline{\text { in }} \\
\text { fog. Hodgson (1997) }\end{array}$ \\
\hline Albanian language & English language \\
\hline $\begin{array}{l}\text { Ex6: Ajo gota e vogël, e verdhe, e konjakut nisi } \\
\text { t’i ja dëbonte përherë e më shumë pamjen e } \\
\text { hirnosur e kërcenonjëse të_maleve... Kadare }\end{array}$ & $\begin{array}{l}\text { Ex6: The little amber glass of cognak was } \\
\text { gradually erasing the memory of those menacing } \\
\text { mountains .... Colman (2000) }\end{array}$ \\
\hline
\end{tabular}

The vice versa that we named as extensive correlation was the case when there is a simple adjective phrase which modifies a noun in the predicative position in the Albanian language, but in the translated paradigm in the English language, there is an complex adjectival phrase to express the idea. To illustrate this case there are the examples below:

\begin{tabular}{|l|l|}
\hline Albanian language & English language \\
\hline $\begin{array}{l}\text { Ex7: .... tek vështronte profilin e ngurtë të priftit. } \\
\text { Kadare (1980) }\end{array}$ & $\begin{array}{l}\text { Ex7 thought to himself as he sat looking at the } \\
\text { priest' severe profile and impassive, masklike } \\
\text { features. Colman (2000) }\end{array}$ \\
\hline Albanian language & English language \\
\hline $\begin{array}{l}\text { Ex 8: Eshtë i bukur, mendoi gienerali ...... } \\
\text { Kadare (1980) }\end{array}$ & $\begin{array}{l}\text { Ex 8/9: A good loking man, thought the general.. } \\
\text { Colman (2000) }\end{array}$ \\
\hline
\end{tabular}


The next case that we noticed was when the place of the adjectives in the sentence was the same in both languages, Albanian and English. We named this case as complete correlation because not only the position of the adjectives was the same, but the construction of the adjective phrase was the same and, the number of adjectives in adjectival phrase used in the translation paradigms was the same. Here are some examples which were notified during our research.

\begin{tabular}{|l|l|}
\hline Albanian language & English language \\
\hline $\begin{array}{l}\text { Ex9: Vec kësaj sot ata kanë marrë rrogat dhe } \\
\text { me siguri kanë blerë ndonjë shishe raki. } \\
\text { Kadare (1980) }\end{array}$ & $\begin{array}{l}\text { Ex9: They were paid today of course, and they } \\
\text { must certainly have brought a bottle of raki. } \\
\text { Colman (2000) }\end{array}$ \\
\hline Albanian language & English language \\
\hline $\begin{array}{l}\text { Ex10: Ai kish hapur në tavolinë planin e } \\
\text { hollësishëm topografik të varrezës dhe po bënte }\end{array}$ & $\begin{array}{l}\text { Ex10: The general had unfolded their large } \\
\text { scale map of the cemetery and was penciling } \\
\text { shënime në të. Kadare (1980) }\end{array}$ \\
\hline
\end{tabular}

\section{Conclusion}

The general and the most frequent rule of sentential adjectival position in Albanian language is noun+adjective, while in English it is adjective+noun. Albanian adjectives have grammatical categories of gender, number and case agreement with the noun that they define. They are inflected to exhibit grammatical relations other than the main form. They usually follow the noun that modify and are remarkable in requiring a particle preceding them in order to agree with the noun. While, in English, adjectives do not change, they remain constant in number and gender. Just as in Albanian also in English, the adjective is used as modifier of the noun in the function of the predicate, subject or object. When it comes to the change of the order, in both languages it is applied only in special cases or only for stylistic reasons.

Regarding the sentential place of adjectives during translation from the Albanian to the English language we noticed the following cases: complete correlation and different correlation. Complete correlation was the situation when the place of adjectives and adjective phrases in the sentence together with the construction of the adjective phrase, was the same in both languages. Different correlation was the case where the place of adjectives and adjective phrases was totally different in both of the languages. Within this case there were two sub cases named as extensive and intensive correlation. Extensive correlation was when there was a simple adjective construction which modifies a noun in the predicative position in Albanian, but in the translated paradigm in English, there was a complex adjectival phrase to express the same idea. Intensive correlation was the vice versa case, when there was a complex adjective phrase in Albanian used attributively after the noun it modified but the construction of the adjective phrase in the translated paradigm in English was a simple adjective phrase formulated from an adjective and a noun in order to express the same idea.

\section{References}

Akademia e Shkencave e Shqipërisë. (2002). Gramatika e Gjuhës Shqipe 2. Instituti i gjuhësisë dhe i letërsisë: Tiranë: pg. 101-102

Alexander, LG . (1988). English Grammar. Hongkong: Longman. pg.110-111.

Beci, B. (2004). Gramatika e Gjuhës Shqipe për të gjithë. EDFA, Tiranë: pg.78

Bauer, L. (2004). Adjectives, compounds and words. In Nordic journal of English Studies 3/1 (= Worlds of Words: A tribute to Arne Zettersten). pg. 7-22

Baskervill, W. M. \& Sewell, J. W. (1986). An English Grammar. Longman. Gmbh Hamburg, Germany. pg.80-82.

Bolinger, D. (1967). Adjectives in English: attribution and predication. Lingua 18: 1-34

Gorgevic, R. (1982). Uvod u kontrastiranje jezika. Beograd: Filoloshki Fakultet. pg.18-23.

Levenston, E.A. (1965). The Translation Paradigm (A Technique for Contrastive Syntax). IRAL, 3 (3). pg. 221-225.

Quirk, R. \& Greenbaum, S. (1991). A student's Grammar of the English Language’' Longman. pg.88-89.

Qitaku, F. (2009). Gramatika e gjuhës shqipe I . Prishtinë: Zero Print. pg.41-47.

\section{List of the corpus books}

Kadare, I. (1980). Ura me tri harqe. Prishtinë: Rilindja: pg. 28, 14.

Hodgson, J. (1997). The three arched bridge. New York: Arcade Publishing House: pg. 23, 11.

Kadare, I. (1980). Gjenerali i ushtrisë së vdekur. Prishtinë: Rilindja: pg. 26, 94, 25, 30.

Colman, D. (1980). The general of the dead army. London: Harvill Pres: pg. 19, 87,8,15. 